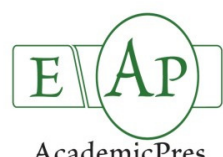

AcademicPres

\title{
The Simultaneous Effect of Water Supply and Genotype on Yield Quantity, Antioxidants Content and Composition of Processing Tomatoes
}

\author{
Lajos HELYES ${ }^{1}$, Andrea LUGASI ${ }^{2}$, Hussein G. DAOOD ${ }^{3}$, Zoltán PÉK ${ }^{1 *}$ \\ ${ }^{1}$ Szent István University, Horticultural Institute, Páter K.út 1., H-2103 Gödöllö, Hungary; Helyes.Lajos@mkk.szie.hu, \\ Pek.Zoltan@mkk.szie.hu (*orrespondingauthor) \\ ${ }^{2}$ Budapest Business School, College of Commerce, Catering and Tourism, Department of Catering; Alkotmány u. 9-11., Budapest, H-1054, \\ Hungary; lugasi_andrea@citromail.hu \\ ${ }^{3}$ Szent István University, Regional Knowledge Center, Páter K. u. 1., Gödöllö, H-2100, Hungary; Daood.Hussein@fh.szie.hu
}

\begin{abstract}
An open field experiment was carried out two years, in order to study the simultaneous effect of water supply and examined varieties on the yield parameters (marketable yield, ${ }^{\circ}$ Brix and ${ }^{\circ}$ Brix yield) and main antioxidant components (carotenoids, mainly lycopene, phenolic compounds and tocopherols) in two different type of processing tomatoes. It was conducted in the Experimental Farms of the Institute of Horticulture at Szent István University, Gödöllő, Hungary. 'Brixsol' $F_{1}$ (normal average fruit weight) and 'Strombolino' $\mathrm{F}_{1}$ (cherry type) varieties were used. Climatic conditions were significantly different in the two seasons. Increasing the water supply increased fruit yield but reduced antioxidants of individual fruits, by inducing more and larger fruits, and by its dilution effects. We have measured significantly higher carotenoids and polyphenols content by processing cherry type hybrid 'Strombolino' $F_{1}$. In general, we can state that irrigation decreased (most cases significantly) carotenoids, polyphenol and tocopherol concentrations in tomato fruits.
\end{abstract}

Keywords: carotenoid, polyphenol, processing tomato, tocophenol

\section{Introduction}

Phytonutrients (also referred to as phytochemicals) are certain natural components of plants. Vegetables (tomato, sweet pepper, eggplant, broccoli, carrot, onion, etc.) are rich sources of phytonutrients. WHO places low fruit and vegetable intake sixth on its list of 20 risk factors for mortality worldwide (WHO, 1990). The importance of tomato cultivation has been growing rapidly in the last decades in the world. Beside the fresh market tomatoes, the processing tomato has a great importance in the food industry, basically because of its health promoting features (Clinton et al., 1996). Bioactive composition of tomatoes is complex and very difficult to assess. Levels of plant metabolites are strongly affected by genetic and environmental factors as well as transportation and storage conditions (Hanson et al., 2004). The growth factors such as light, temperature, humidity, type of soil, application of fertilizers, damage caused by microorganisms and insects, stress induced by UV radiation, heavy metals, and pesticides all alter metabolite composition of plants (Orcutt and Nilsen, 2000; Helyes and Lugasi, 2006; Helyes et al., 2006; Pék et al., 2010).

There are several reports on the effect of irrigation on tomato yield, dry matter and fruit soluble solids content.
Pernice et al. (2010) found, that tomatoes produced an average yield of almost $100 \mathrm{t} \mathrm{ha}^{-1}$. Yield was greatly influenced by the water regime; when comparing no irrigation to the reduced irrigation condition a considerable increase was observed in average yield $(+45.7 \%)$. Similarly Liu et al. (2011) reported that drip irrigation compared to nonirrigation, increased tomato fruit size by $32 \%$. Others (Patanè and Cosentino, 2010) also reported this marked influence of irrigation on tomato fruit size. Liu et al. (2011) found that irrigation also increased marketable fruit yield by $127 \%$ and total fruit yield by $66 \%$, while it decreased soluble solids content by $19 \%$ which was also reported by Favati $e t$ al. (2009). In summary the greatest effect of increasing soil water deficit is the rise in soluble solids, total solids and fruit firmness, and a decrease in fruit size and yield (Patanè and Cosentino, 2010).

More than 700 carotenoids have been isolated from different plant sources. Lycopene is the most important carotenoid in tomato fruit (Rao, 2006). Chlorophyll breaks down and carotenoids, mostly lycopene, accumulate during ripening (Biacs and Daood, 2000). García-Valverde et al. (2013) reported from 83.2 to $97.6 \mathrm{mg} \mathrm{kg}^{-1} \mathrm{fw}$. total lycopene and from 3.0 to $6.1 \mathrm{mg} \mathrm{kg}^{-1} \mathrm{fw}$. $\beta$-carotene in the fruits of five processing tomato cultivars. Liu et al. (2011) reported that lycopene content decreased by $8 \%$ in irrigated 
compared to nonirrigated conditions. While Riggi et al. (2008) found that in the well watered treatment higher amounts of lycopene were measured, regardless of the ripening stage. They also found that $\beta$-carotene content was positively affected by water stress. Particularly in the first 2 ripening stages $\beta$-carotene/lycopene ratio was also influenced by water stress and suggested that, the carotenoid biosynthetic pathway is more ' $\beta$-carotene accumulation' oriented under soil water deficit conditions. Favati et al. (2009) also found that compared to well irrigated the lycopene and $\beta$-carotene concentration was higher in less irrigated tomatoes.

The term phenolic antioxidant refers to both simple phenolic acids and flavonoids. Tomato fruits are also rich in polyphenols that amount to the largest part of the antioxidant capacity of the soluble phase (Inert et al., 2009).

In the case of tomatoes, several studies point to high levels of vitamin $\mathrm{E}$ in the processed product (Abushita $e$ t al., 2000; Seybold et al., 2004). Tomatoes at the ripening stage contain $\alpha$-tocopherol and $\gamma$-tocopherol at the average concentration of 3.5 and $1.2 \mathrm{~g} / \mathrm{g}$, respectively (Abushita $e t$ al., 1997).

The aim of the present study was to evaluate the influence of genetic and environmental factors (temperature and water supply) on yield quantity and quality, especially on the content of carotenoids (lycopene and its isomers, $\beta$-carotene), phenolic compounds (flavonoids and phenolic acids and total phenolics) and tocopherols in a cherry tomato, compared with a normal fruit weight variety.

\section{Materials and methods}

\section{Plant material}

This experiment was conducted at the Experimental Farm of the Institute of Horticultural, Szent István University, in Gödöllö, Hungary. The experimental field is on brown forest soil, with mechanical composition of sand, sandy-clay and the subsoil water is below $5 \mathrm{~m}$, therefore it cannot influence the water turnover. 'Brixsol' $F_{1}$ (normal average fruit weight) 'Strombolino' $F_{1}$ (cherry type) seeds were sown on the $2^{\text {nd }}$ of April in 2010 and $7^{\text {th }}$ of April in 2011 in greenhouse and transplanted on the $14^{\text {th }}$ of May 2010 and $12^{\text {th }}$ of May in 2011. The experimental design was randomized block, number of replications were four for each treatment. Tomato plants were arranged in double (twin) rows with a distance of 1.2 and $0.4 \mathrm{~m}$ between the rows and $0.3 \mathrm{~m}$ between the plants. Crop density was 4.2 plant $/ \mathrm{m}^{2}$. Regularly irrigated and control (with no irrigation) were the two different water supply treatments applied in the present work. The amount of irrigation supply was calculated from weather forecasting data of the Hungarian Meteorological Service (2011). The amount of daily irrigation demand was estimated from expected daily potential evapotranspiration according to a previous study (Helyes and Varga, 1994).

In drip irrigation the water was given in accordance with air temperature (daily irrigation water $(\mathrm{mm})=$ average daily temperature $\times 0.2$ ). National Meteorological Institute forecasts were used to calculate the probable air temperature. It is important to note that precipitation of
2010 was very extreme, because the highest rainfall in the last hundred years was measured that year in Hungary. Water amounts of 558 and $410 \mathrm{~mm}$ in 2010 and 524 and $159 \mathrm{~mm}$ in 2011 were usable for plants in irrigation treatment and unirrigated control respectively during the vegetation period (Fig. 1). Fruits were measured at harvesting on the $6^{\text {th }}$ of August in 2010 and $26^{\text {th }}$ of July and $26^{\text {th }}$ of August in 2011.

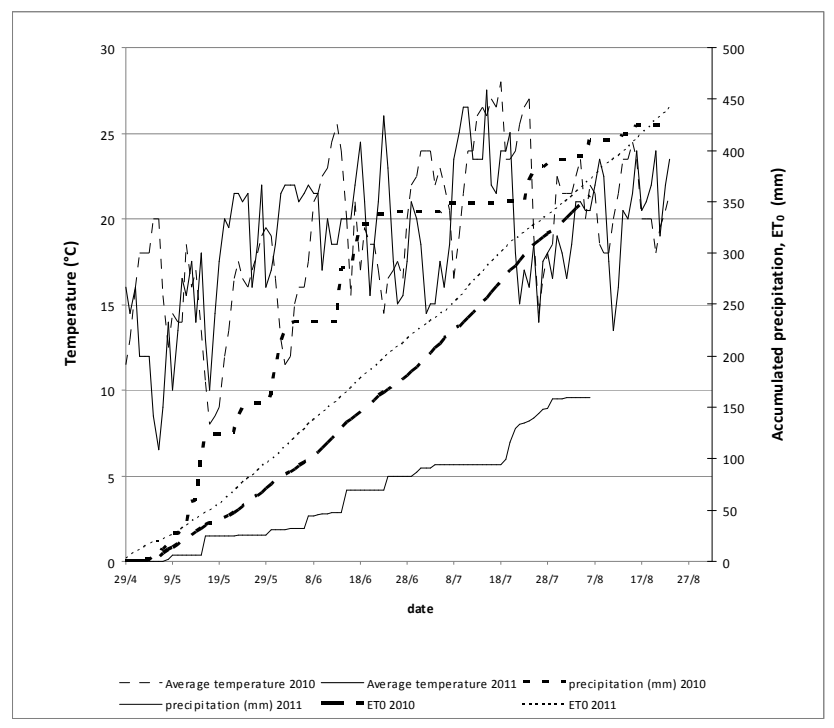

Fig. 1. Meteorological data during tomato vegetation period in 2010 and 2011

\section{Measurement of environmental parameters}

Changes of the environmental factors were monitored via measuring three parameters. During the experiment we defined the air temperature $\left({ }^{\circ} \mathrm{C}\right)$, relative humidity $(\mathrm{RH} \%)$ and incoming light intensity $\left(\mu \mathrm{mol} \mathrm{m} \mathrm{s}^{-2}\right)$. Temperature, relative humidity and photosynthetically active radiation (not shown) were measured six times per hour using a SKYE DataHog micrometeorological instrument, placed at two meters height (Skye Instruments Ltd, Llandrindrod Wells, UK).

\section{Analysis of quality components}

Extraction of carotenoids, tocopherols. Lipids and fatsoluble pigments and tocopherols from raw tomato were extracted according to a previously described procedure with slight modification (Abushita et al., 1997). Five-gram samples from tomato fruits were taken in triplicate (at least) and disintegrated in a crucible mortar in the presence of quartz sand. The water was removed by adding $25 \mathrm{~mL}$ of methanol with further disintegration of the aggregating bulk. The mixture was then transferred quantitatively to a $100 \mathrm{~mL}$ conical flask, and $70 \mathrm{~mL}$ of a 6:1 dichloroethanemethanol solution was added. The mixture was shaken for 15 min by a mechanical shaker. A few drops of distilled water were added when the dichloroethane phase was not clearly separated from the polar phase (water + methanol). A separatory funnel separated the two phases, and the lower layer containing lipids in dichloroethane was dried over anhydrous sodium sulfate. Finally, the organic solvent was evaporated under vacuum by rotary evaporator (IKA RV 
145

10, Sigma-Aldrich Ltd., Budapest, Hungary) at not higher than $40{ }^{\circ} \mathrm{C}$. The residues were either redissolved in the HPLC eluent for analysis of carotenoids or saponified for analysis of tocopherols.

HPLC equipments and conditions. To analyse carotenoid and flavonoid type compounds, a Waters Alliance liquid chromatographic instrument consisting of a Model 2696 Separation Module (Gradient pump, autosampler and column heater) and a Model 2695 photodiode array detector was used. Operation and data processing were performed by Empower software.

The separation of carotenoids was performed on Crosslinked-C18 (240 _ $4.6 \mathrm{~mm}$ i.d.) $3 \mu \mathrm{m}$ ISIS column using gradients elution starting with $20 \%$ water in acetone and ending with $5 \%$ water in acetone with a flow rate of 0.7 $\mathrm{mL} / \mathrm{min}$ according to Daood et al. (2013). The column effluents were detected at their maximum absorption wavelength lycopene, $\beta$-carotene and zeaxanthin were identified and quantified using standard materials purchased from Sigma-Aldrich Ltd. (Budapest, Hungary). Identification of other compounds was based on their retention time, spectral characteristics and mass spectrum data array). They were quantified as either lycopene- or $\beta$ carotene-equivalent according to their spectral characteristics (Fig. 2).

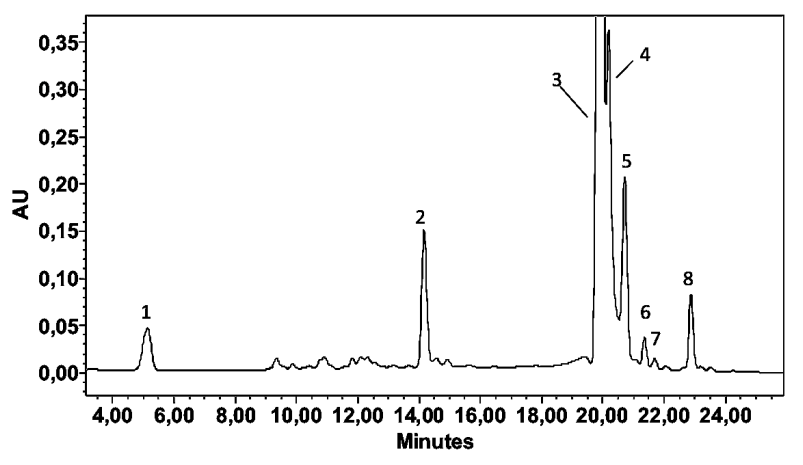

Fig. 2. HPLC profile of tomato carotenoids separated on crosslinked C18 column with gradient elution of water in acetone (for more details see text). Peak identification as: 1: zeaxanthin, 2: lycoxanthin, 3: lycopene, 4 and 5: cis-lycopene, 6: unidentified, 7 gamma-caotene, 8 : beta-carotene

For tocopherol analysis, a combination of a Beckman $114 \mathrm{M}$ isocratic pump, a model RF-535 Shimadzu fluorometric detector, and a Waters-740 Data Module integrator was used. The separation was performed on Lichosorb $5 \mu \mathrm{m}(250$ _ $4.6 \mathrm{~mm}$ i.d.) with a mobile phase consisting of 99.5:0.5 n-hexane-ethanol. The fluorometric detector was set at 295 and $320 \mathrm{~nm}$ as the excitation and emission wavelength, respectively (Abushita et al., 1997) (Fig. 3).

The phenolic compounds were determined by RPHPLC. Sample preparation and extraction: Tomato sample was homogenised by a warring blender, $10 \mathrm{~g}$ was weighed into an Erlenmeyer flask, $10 \mathrm{ml}$ distilled water was added to the sample and placed in ultrasonic bath for $30 \mathrm{sec} ., 15 \mathrm{ml}$ of $2 \%$ acetic acid in methanol was added to the mixture. Mechanical shaker shook the mixture for 15 minutes. The flask was kept at $4{ }^{\circ} \mathrm{C}$ for overnight. Next day, the filtrate

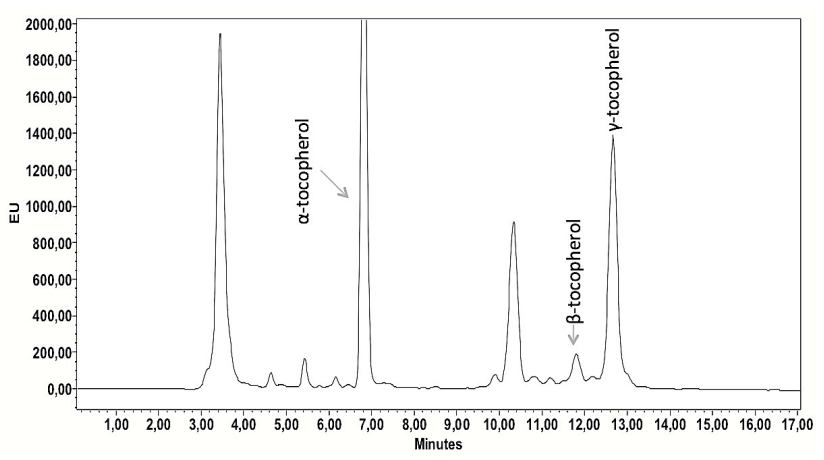

Fig. 3. Separation of tocopherol analogues from tomato by normal-phase HPLC using n-hexane-ethanol, 99.5:0.5, as the mobile phase and fluorescence detection (excitation $295 \mathrm{~nm}$, emission $320 \mathrm{~nm}$ )

was cleaned further by passing through $0.45 \mu \mathrm{m}$ HPLC syringe filter before injection onto HPLC column for analysis of phenolic compounds. The analytical column was EC NUCLEODUR Sphinx RP (Symetron Ltd. Budapest, Hungary), $3 \mu \mathrm{m}, 150 \times 4.6$. The mobile phase was [B] $1 \%$ formic acid in water, [C] acetonitril and a flow rate of 0.6 $\mathrm{ml} / \mathrm{min}$. Injected volume was $20 \mu \mathrm{l}$. Phenols having absorption maxima around $280 \mathrm{~nm}$ were quantified as gallic acid- equivalent, while flavonoids were quantified as rutinequivalent at $320 \mathrm{~nm}$ and $355 \mathrm{~nm}$. Peaks of phenol components were identified by comparing their spectral characteristics and retention with those of available standards (apigenin, caffeic acid glucoside, chlorogenic acid, sinapic acid glucoside, and ferulic acid; Sigma-Aldrich Ltd. Budapest, Hungary) (Pék et al., 2013) (Fig. 4).

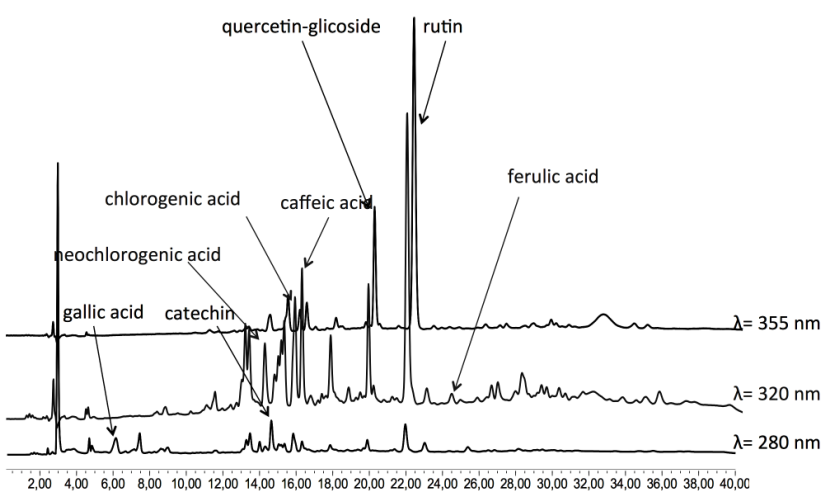

Fig. 4. HPLC profile of tomato phenols separated EC NUCLEODUR Sphinx RP with gradient elution of water in formic acid and acetonitril

\section{Statistical analysis}

The data were analysed by two-factor analysis of variance (ANOVA) with repetitions and the means separated using the Student's test at $\mathrm{p}=0.05$.

\section{Results and discussion}

The effect of irrigation on tomato yield parameters depends on the actual weather conditions, basically the air temperature and precipitation (quantity and distribution). 
Fig. 1 shows daily average temperature and precipitations during the vegetation period in these two years. It is also important to note that precipitation of 2010 was very extreme, because the highest rainfall in the last hundred years was measured that year in Hungary.

Average daily precipitation was almost three times more $(4.1 \mathrm{~mm})$ in 2010, than in $2011(1.4 \mathrm{~mm})$ during the crop season.

The two cultivars differ basically in average fruit weight, so normal processing type 'Brixsol' F1 produced higher yield than cherry type 'Strombolino' F1, but it was significant only in 2011. The irrigated plants gave significantly higher yield quantity in both years, while unirrigated plants showed yield loss particularly in 2011 (Tab. 1), which is in agreement with previous studies of processing tomatoes (Barbagallo et al., 2013; Helyes et al., 2012).

The effect of irrigation on processing tomato is complex; through the number of flowers and the percentage of fruit set it first increases the number of fruits per plant, and then enlarges the size of fruits (Wudiri and Henderson, 1985).

Better water supply caused lower ${ }^{\circ}$ Brix, than control. The soluble solid content of fruits was often very high without irrigation. In spite of this, the level of Brix yield per hectare remarkably increased as a result of significantly higher yield quantity (Tab. 2). Greatest effect of increasing soil water deficit was the rise in fruit firmness, soluble solids and a decrease in fruit size and yield, which is in agreement with Patanè and Cosentino (2010).

In this study we evaluated total carotenoid, polyphenol and tocopherol contents and their composition depending on tested cultivars and water supplement in 2010 and 2011. During the two-year experiment, we found that the total carotenoid concentration of the tomato fruits ranged from
52.5 to $109.2 \mathrm{mg} \mathrm{kg}^{-1}$. This is nearly a twofold difference. Cherry type tomatoes contain significantly higher lycopene concentration than large fruited cultivars (Helyes and Lugasi, 2006; Kuti and Konuru, 2005). StC gave the highest total carotenoid content $\left(109.2 \mathrm{mg} \mathrm{kg}^{-1}\right)$ in July 2011, because of the cooler weather conditions (Dumas et al., 2003) (Tab. 3). During the ten days preceding the $26^{\text {th }}$ of July harvest, the average maximum temperature was 25.2 ${ }^{\circ} \mathrm{C}$, the average minimum temperature was $14.5^{\circ} \mathrm{C}$ and every day was a little rainy and cloudy. On the contrary, the ten days preceding the $26^{\text {th }}$ of August harvest was much warmer. The average daily minimum temperature was 14.2 ${ }^{\circ} \mathrm{C}$, the average maximum temperature was $29.3^{\circ} \mathrm{C}$ and the maximum temperature reached or was above $30^{\circ} \mathrm{C}$ five times. It is important to note that the average cis-lycopene ratio was significantly higher in case of 'Strombolino' $F_{1}$ in 2011, particularly in the second harvest (Tab. 3). Since irrigation also decreased lycopene concentration, thus to

Tab. 2. Soluble solid content $\left({ }^{\circ}\right.$ Brix $)$ and Brix yield $\left(t \mathrm{tha}^{-1}\right)$ of tomatoes under different water supply in 2010 and $2011(n=4 ; \pm$ SD)

\begin{tabular}{ccccc}
\hline \multirow{2}{*}{$\begin{array}{c}\text { Cultivars } \\
\text { and } \\
\text { treatments }\end{array}$} & \multicolumn{2}{c}{2010} & \multicolumn{2}{c}{2011} \\
\cline { 2 - 5 } & ${ }^{\circ}$ Brix & Brix yield & ${ }^{\circ}$ Brix & Brix yield \\
\hline BI & $4.58 \pm 0.12^{\mathrm{a}}$ & $1.80 \pm 0.42^{\mathrm{a}}$ & $5.33 \pm 0.17^{\mathrm{a}}$ & $5.44 \pm 0.55^{\mathrm{c}}$ \\
BC & $5.03 \pm 0.21^{\mathrm{a}}$ & $1.35 \pm 0.16^{\mathrm{a}}$ & $7.25 \pm 0.65^{\mathrm{bc}}$ & $3.54 \pm 0.84^{\mathrm{b}}$ \\
STI & $5.44 \pm 0.08^{\mathrm{b}}$ & $1.52 \pm 0.15^{\mathrm{a}}$ & $6.63 \pm 0.19^{\mathrm{b}}$ & $3.59 \pm 0.62^{\mathrm{b}}$ \\
STC & $5.98 \pm 0.12^{\mathrm{c}}$ & $1.44 \pm 0.34^{\mathrm{a}}$ & $7.48 \pm 0.49^{\mathrm{c}}$ & $1.97 \pm 0.48^{\mathrm{a}}$ \\
\hline
\end{tabular}

BI: 'Brixsol' irrigated, BC: 'Brixsol' control, StI: 'Strombolino' irrigated, StC: 'Strombolino' control.

Values are reported as the mean \pm standard deviation. Means in a column with different letters are significantly different at $\mathrm{p}=0.05$.

Tab. 1. Quantitative yield parameters $\left(\mathrm{tha}^{-1}\right)$ of tomatoes under different water supply in 2010 and $2011(\mathrm{n}=4 ; \pm \mathrm{SD})$

\begin{tabular}{|c|c|c|c|c|c|c|}
\hline \multirow{2}{*}{$\begin{array}{l}\text { Cultivars } \\
\text { and } \\
\text { treatments }\end{array}$} & \multicolumn{3}{|c|}{2010} & \multicolumn{3}{|c|}{2011} \\
\hline & Red yield & Green yield & Marketable yield & Red yield & Green yield & Marketable yield \\
\hline BI & $39.2 \pm 8.1^{b}$ & $10.2 \pm 2.2^{b}$ & $49.4 \pm 5.1^{b}$ & $102.1 \pm 7.0^{\mathrm{c}}$ & $18.7 \pm 3.4^{\mathrm{c}}$ & $120.8 \pm 5.5^{c}$ \\
\hline $\mathrm{BC}$ & $26.8 \pm 2.1^{a}$ & $4.2 \pm 0.6^{\mathrm{a}}$ & $31.0 \pm 1.6^{a}$ & $48.8 \pm 7.2^{\mathrm{a}}$ & $14.4 \pm 1.7^{b}$ & $63.2 \pm 3.8^{b}$ \\
\hline StI & $27.9 \pm 7.1^{\mathrm{ab}}$ & $14.5 \pm 3.9^{b}$ & $42.4 \pm 5.5^{b}$ & $54.1 \pm 7.8^{b}$ & $5.6 \pm 3.7^{a}$ & $59.7 \pm 5.7^{b}$ \\
\hline $\mathrm{StC}$ & $24.0 \pm 1.6^{\mathrm{a}}$ & $6.0 \pm 2.1^{\mathrm{a}}$ & $30.0 \pm 1.8^{a}$ & $26.4 \pm 4.7^{\mathrm{a}}$ & $7.1 \pm 2.8^{a}$ & $33.5 \pm 3.7^{a}$ \\
\hline
\end{tabular}

BI: 'Brixsol' irrigated, BC: 'Brixsol' control, StI: 'Strombolino' irrigated, StC: 'Strombolino' control.

Tab. 3. Carotenoid components $\left(\mathrm{mg} \mathrm{kg}^{-1} \mathrm{FW}\right)$ of tomatoes under different water supply in 2010 and $2011(\mathrm{n}=4 ; \pm \mathrm{SD})$

\begin{tabular}{ccccccccc}
\hline $\begin{array}{c}\text { Harvesting } \\
\text { date }\end{array}$ & $\begin{array}{c}\text { Cultivars and } \\
\text { treatments }\end{array}$ & Zeaxanthin & Lycoxanthin & Lycopene & $\begin{array}{c}9 Z+13 Z \\
\text { Lycopene }\end{array}$ & $\beta$-carotene & $\gamma$-carotene & Phytoene \\
\hline 06.8 .2010 & BI & $0.33 \pm 0.06^{\mathrm{c}}$ & $0.83 \pm 0.09^{\mathrm{ab}}$ & $43.6 \pm 3.12^{\mathrm{a}}$ & $3.40 \pm 0.98^{\mathrm{a}}$ & $2.85 \pm 0.25^{\mathrm{bc}}$ & $0.19 \pm 0.03^{\mathrm{a}}$ & $1.27 \pm 0.19^{\mathrm{a}}$ \\
& $\mathrm{BC}$ & $0.35 \pm 0.04^{\mathrm{c}}$ & $0.52 \pm 0.04^{\mathrm{a}}$ & $41.7 \pm 4.10^{\mathrm{a}}$ & $6.81 \pm 1.38^{\mathrm{b}}$ & $2.47 \pm 0.34^{\mathrm{b}}$ & $0.23 \pm 0.03^{\mathrm{ab}}$ & $1.72 \pm 0.08^{\mathrm{a}}$ \\
& $\mathrm{StI}$ & $0.47 \pm 0.07^{\mathrm{c}}$ & $1.05 \pm 0.07^{\mathrm{ab}}$ & $48.3 \pm 4.78^{\mathrm{a}}$ & $4.55 \pm 0.74^{\mathrm{a}}$ & $3.63 \pm 0.50^{\mathrm{c}}$ & $0.32 \pm 0.04^{\mathrm{c}}$ & $2.02 \pm 0.21^{\mathrm{b}}$ \\
& $\mathrm{StC}$ & $0.57 \pm 0.01^{\mathrm{c}}$ & $1.49 \pm 0.06^{\mathrm{b}}$ & $62.6 \pm 2.77^{\mathrm{b}}$ & $2.98 \pm 1.21^{\mathrm{a}}$ & $3.27 \pm 0.17^{\mathrm{c}}$ & $0.28 \pm 0.02^{\mathrm{c}}$ & $1.69 \pm 0.13^{\mathrm{a}}$ \\
26.7 .2011 & $\mathrm{StI}$ & $0.28 \pm 0.10^{\mathrm{b}}$ & $0.86 \pm 0.20^{\mathrm{a}}$ & $73.5 \pm 15.8^{\mathrm{bc}}$ & $8.30 \pm 1.66^{\mathrm{bc}}$ & $2.77 \pm 0.23^{\mathrm{b}}$ & $0.24 \pm 0.01^{\mathrm{b}}$ & $1.61 \pm 0.19^{\mathrm{a}}$ \\
& $\mathrm{StC}$ & $0.18 \pm 0.03^{\mathrm{a}}$ & $1.55 \pm 0.23^{\mathrm{b}}$ & $95.8 \pm 10.2^{\mathrm{c}}$ & $7.51 \pm 1.93^{\mathrm{b}}$ & $2.40 \pm 0.31^{\mathrm{b}}$ & $0.21 \pm 0.03^{\mathrm{a}}$ & $1.51 \pm 0.07^{\mathrm{a}}$ \\
26.8 .2011 & $\mathrm{BI}$ & $0.21 \pm 0.02^{\mathrm{a}}$ & $0.69 \pm 0.15^{\mathrm{a}}$ & $39.3 \pm 11.7^{\mathrm{a}}$ & $9.95 \pm 0.57^{\mathrm{c}}$ & $1.16 \pm 0.14^{\mathrm{a}}$ & $0.31 \pm 0.01^{\mathrm{c}}$ & $1.95 \pm 0.21^{\mathrm{ab}}$ \\
& $\mathrm{BC}$ & $0.37 \pm 0.14^{\mathrm{bc}}$ & $1.32 \pm 0.35^{\mathrm{b}}$ & $48.9 \pm 6.4^{\mathrm{a}}$ & $15.11 \pm 1.01^{\mathrm{e}}$ & $1.12 \pm 0.11^{\mathrm{a}}$ & $0.29 \pm 0.05^{\mathrm{c}}$ & $2.33 \pm 0.50^{\mathrm{abc}}$ \\
& $\mathrm{StI}$ & $0.24 \pm 0.01^{\mathrm{ab}}$ & $0.78 \pm 0.28^{\mathrm{a}}$ & $57.3 \pm 19.4^{\mathrm{ab}}$ & $13.60 \pm 0.32^{\mathrm{d}}$ & $3.45 \pm 0.26^{\mathrm{c}}$ & $0.25 \pm 0.04^{\mathrm{ab}}$ & $2.76 \pm 0.32^{\mathrm{c}}$ \\
& $\mathrm{StC}$ & $0.41 \pm 0.07^{\mathrm{c}}$ & $1.53 \pm 0.42^{\mathrm{b}}$ & $72.1 \pm 24.5^{\mathrm{abc}}$ & $19.57 \pm 1.85^{\mathrm{f}}$ & $3.70 \pm 0.79^{\mathrm{c}}$ & $0.48 \pm 0.11^{\mathrm{d}}$ & $2.55 \pm 0.57^{\mathrm{bc}}$ \\
\hline
\end{tabular}

BI: 'Brixsol' irrigated, BC: 'Brixsol' control, StI: 'Strombolino' irrigated, StC: 'Strombolino' control.

Values are reported as the mean \pm standard deviation. Data in the same column bearing the same superscript letter are not significant at $\mathrm{p}=0.05$. 
147

improve fruit yield and lycopene concentration of tomatoes, Sánchez-Rodríguez et al. (2012) suggest moderate water stress. Irrigation probably indirectly affected lycopene concentration by inducing more and larger fruits, and thus had a dilution effect on ingredients. By the higher lycopene production per unit area the higher yield could account for the concentration loss of individual fruits (Helyes et al., 2012).

The all-trans form of lycopene of tomato fruits was higher, while $c i s$-isomers of lycopene were lower in all of the cultivars and harvests. The average cis-lycopene concentration was significantly higher in 2011 than in 2010 , and it was nearly two-fold higher in case of 'Strombolino' at the second harvest date in 2011. It seems probable that the warmer temperatures and a better light supply activated the biosynthesis of cis-isomers of lycopene in 2011, which is in agreement with Kuti and Konuru (2005).

Tab. 4 shows the effect of water supply and examined varieties on the concentration of polyphenol groups (flavonoids and phenolic acids). We have measured significantly lower flavonoids and phenolic acids concentration in irrigated samples, which is contradictory to the findings of Sánchez-Rodríguez et al. (2012), in tomato grown in a growth chamber near optimal environmental conditions. Phenolic acids results showed the same pattern as flavonoids and ranged between $30.7-154.1 \mathrm{mg} \mathrm{kg}^{-1}$. Irrigated samples gave lower values, in agreement with Sánchez-Rodríguez et al. (2012), who reported lower phenolic acids concentration of cherry tomato fruits under moderate water stress conditions.

In the examined tomato samples we could identify nine components of polyphenols. These are the following: neochlorogenic acid, chlorogenic acid, caffeic acid, ferulic acid, gallic acid, quercetin, rutin, catechin, naringin (Tab. 5.). In our experiment the average rutin content ranged from 41.7 to $98.8 \mathrm{mg} \mathrm{kg}^{-1}$. This is more than a double difference, and in all samples, the rutin concentration showed significant decrease with irrigation. The second largest concentration was found to be of chlorogenic acid. We could not measured detectable amount of naringin in 'Brixsol' F1. Riga et al. (2008) found strong negative correlation between cumulative temperature during the 45 days before harvest and total phenolic concentration. Also lower phenolics content of fresh tomato fruit was reported at higher temperatures (Incerti et al., 2009), and our results could confirm this temperature effect. Probably seasonal

Tab. 4. Concentration of polyphenols $\left(\mathrm{mg} \mathrm{kg}^{-1} \mathrm{FW}\right)$ of tomatoes under different water supply in 2010 and $2011(n=4, \pm$ SD)

\begin{tabular}{cccc}
\hline $\begin{array}{c}\text { Harvesting } \\
\text { date }\end{array}$ & $\begin{array}{c}\text { Cultivars and } \\
\text { treatments }\end{array}$ & $\begin{array}{c}\text { Flavonoids } \\
\left(\mathrm{mg} \mathrm{kg}^{-1}\right)\end{array}$ & $\begin{array}{c}\text { Phenolic acids } \\
\left(\mathrm{mg} \mathrm{kg}^{-1}\right)\end{array}$ \\
\hline & $\mathrm{BI}$ & $25.7 \pm 2.5 \mathrm{a}$ & $30.7 \pm 3.6 \mathrm{a}$ \\
06.8 .2010 & $\mathrm{BC}$ & $69.9 \pm 8.7 \mathrm{~cd}$ & $39.9 \pm 4.9 \mathrm{~b}$ \\
& $\mathrm{StI}$ & $81.5 \pm 16.2 \mathrm{~d}$ & $65.9 \pm 8.2 \mathrm{c}$ \\
& $\mathrm{StC}$ & $106.9 \pm 5.3 \mathrm{e}$ & $78.3 \pm 3.7 \mathrm{~d}$ \\
26.7 .2011 & $\mathrm{StI}$ & $69.0 \pm 6.4 \mathrm{~d}$ & $109.0 \pm 15.5 \mathrm{e}$ \\
& $\mathrm{StC}$ & $58.6 \pm 4.3 \mathrm{c}$ & $154.1 \pm 19.4 \mathrm{f}$ \\
& $\mathrm{BI}$ & $22.6 \pm 3.8 \mathrm{a}$ & $31.7 \pm 4.0 \mathrm{a}$ \\
26.8 .2011 & $\mathrm{BC}$ & $37.7 \pm 6.9 \mathrm{~b}$ & $42.2 \pm 5.6 \mathrm{~b}$ \\
& $\mathrm{StI}$ & $81.0 \pm 11.0 \mathrm{~d}$ & $101.1 \pm 12.7 \mathrm{e}$ \\
& $\mathrm{StC}$ & $120.1 \pm 20.4 \mathrm{e}$ & $112.5 \pm 20.2 \mathrm{e}$ \\
\hline
\end{tabular}

BI: 'Brixsol' irrigated, BC: 'Brixsol' control, StI: 'Strombolino' irrigated, StC: 'Strombolino' control.

Values are reported as the mean \pm standard deviation. Data in the same column bearing the same superscript letter are not significant at $\mathrm{p}=0.05$.

Tab. 5. Concentration of main polyphenols $\left(\mathrm{mg} \mathrm{kg}^{-1} \mathrm{FW}\right)$ of cherry tomato under different water supply $(\mathrm{n}=4, \pm \mathrm{SD})$

\begin{tabular}{|c|c|c|c|c|c|c|c|c|c|c|}
\hline $\begin{array}{l}\text { Harves- } \\
\text { ting } \\
\text { date }\end{array}$ & $\begin{array}{l}\text { Cultivars } \\
\text { and } \\
\text { treatments }\end{array}$ & $\begin{array}{l}\text { Quercetin- } \\
\text { glucoside }\end{array}$ & Rutin & Catechin & Naringin & $\begin{array}{l}\text { Neocloro- } \\
\text { genic acid }\end{array}$ & $\begin{array}{l}\text { Clorogenic } \\
\text { acid }\end{array}$ & $\begin{array}{c}\text { Caffeic } \\
\text { acid }\end{array}$ & $\begin{array}{l}\text { Ferulic } \\
\text { acid }\end{array}$ & Gallic acid \\
\hline \multirow{4}{*}{$\begin{array}{l}06.8 . \\
2010\end{array}$} & BI & $7.2 \pm 0.3^{\mathrm{a}}$ & $14.3 \pm 1.6^{\mathrm{a}}$ & $4.3 \pm 0.5^{c}$ & nd & $4.8 \pm 0.6^{\mathrm{a}}$ & $12.4 \pm 1.2^{\mathrm{b}}$ & $7.7 \pm 0.2^{\mathrm{b}}$ & $2.9 \pm 0.4^{\mathrm{b}}$ & $2.9 \pm 1.1^{\mathrm{c}}$ \\
\hline & $\mathrm{BC}$ & $15.3 \pm 1.2^{\text {cd }}$ & $45.8 \pm 5.9^{\mathrm{cd}}$ & $8.8 \pm 1.6^{\mathrm{d}}$ & nd & $9.0 \pm 0.9^{\mathrm{b}}$ & $10.7 \pm 1.0^{\mathrm{b}}$ & $8.7 \pm 1.0^{\mathrm{b}}$ & $3.7 \pm 1.0^{\mathrm{b}}$ & $7.7 \pm 0.9^{f}$ \\
\hline & StI & $13.6 \pm 2.2^{\mathrm{bc}}$ & $46.6 \pm 10.0^{c}$ & $6.0 \pm 2.1^{\mathrm{cd}}$ & $15.3 \pm 1.6^{c}$ & $11.9 \pm 1.4^{c}$ & $26.6 \pm 3.2^{c}$ & $19.7 \pm 2.5^{\mathrm{e}}$ & $3.1 \pm 0.3^{b}$ & $4.7 \pm 0.7^{\mathrm{de}}$ \\
\hline & $\mathrm{StC}$ & $12.8 \pm 0.5^{b}$ & $68.1 \pm 2.5^{\mathrm{e}}$ & $10.4 \pm 1.4^{\mathrm{d}}$ & $15.5 \pm 0.8^{c}$ & $20.5 \pm 0.8^{e}$ & $30.2 \pm 0.9^{\mathrm{d}}$ & $19.4 \pm 1.1^{\mathrm{e}}$ & $3.6 \pm 0.3^{b}$ & $4.5 \pm 0.4^{\mathrm{d}}$ \\
\hline \multirow{2}{*}{$\begin{array}{l}26.7 \\
2011\end{array}$} & StI & $13.2 \pm 0.9^{\mathrm{bc}}$ & $41.7 \pm 1.9^{c}$ & $3.3 \pm 0.4^{\mathrm{b}}$ & $0.3 \pm 0.03^{\mathrm{a}}$ & $13.3 \pm 1.8^{\mathrm{cd}}$ & $45.8 \pm 6.9^{\mathrm{e}}$ & $6.3 \pm 0.6^{a}$ & $5.8 \pm 0.6^{c}$ & $3.0 \pm 0.4^{\mathrm{c}}$ \\
\hline & $\mathrm{StC}$ & $13.4 \pm 1.8^{\mathrm{bc}}$ & $52.2 \pm 4.9^{d}$ & $3.0 \pm 0.4^{b}$ & $0.4 \pm 0.05^{b}$ & $12.0 \pm 1.4^{c}$ & $84.3 \pm 12.4^{\mathrm{f}}$ & $8.0 \pm 0.7^{b}$ & $7.1 \pm 0.5^{d}$ & $1.2 \pm 0.1^{\mathrm{a}}$ \\
\hline \multirow{4}{*}{$\begin{array}{l}26.8 . \\
2011\end{array}$} & BI & $7.8 \pm 1.8^{\mathrm{a}}$ & $11.7 \pm 1.2^{\mathrm{a}}$ & $3.2 \pm 0.8^{\mathrm{bc}}$ & nd & $4.8 \pm 0.6^{\mathrm{a}}$ & $10.9 \pm 1.5^{\mathrm{b}}$ & $5.0 \pm 0.8^{\mathrm{a}}$ & $0.3 \pm 0.1^{\mathrm{a}}$ & $1.5 \pm 0.1^{\mathrm{b}}$ \\
\hline & $\mathrm{BC}$ & $13.1 \pm 3.4^{\mathrm{bc}}$ & $19.1 \pm 2.4^{\mathrm{b}}$ & $5.6 \pm 1.10^{c}$ & nd & $9.2 \pm 1.10^{\mathrm{b}}$ & $7.4 \pm 1.02^{\mathrm{a}}$ & $6.2 \pm 0.8^{\mathrm{a}}$ & $2.0 \pm 0.6^{\mathrm{b}}$ & $1.4 \pm 0.2^{\mathrm{ab}}$ \\
\hline & StI & $13.2 \pm 1.2^{\mathrm{bc}}$ & $65.5 \pm 9.2^{\mathrm{de}}$ & $2.0 \pm 0.3^{\mathrm{a}}$ & $0.4 \pm 0.06^{\mathrm{b}}$ & $15.0 \pm 1.4^{\mathrm{d}}$ & $22.6 \pm 2.9^{c}$ & $11.4 \pm 1.8^{\mathrm{d}}$ & $9.5 \pm 1.8^{\mathrm{e}}$ & $6.5 \pm 0.7^{\mathrm{ef}}$ \\
\hline & $\mathrm{StC}$ & $18.1 \pm 3.4^{\mathrm{d}}$ & $98.8 \pm 16.2^{f}$ & $2.7 \pm 0.4^{\mathrm{ab}}$ & $0.4 \pm 0.05^{\mathrm{b}}$ & $28.9 \pm 4.2^{f}$ & $31.5 \pm 3.0^{\mathrm{d}}$ & $13.1 \pm 2.9^{\mathrm{d}}$ & $12.6 \pm 4.5^{\mathrm{e}}$ & $6.5 \pm 1.2^{\mathrm{def}}$ \\
\hline
\end{tabular}

BI: 'Brixsol' irrigated, BC: 'Brixsol' control, StI: 'Strombolino' irrigated, StC: 'Strombolino' control, nd: not detected.

Values are reported as the mean \pm standard deviation. Data in the same column bearing the same superscript letter are not significant at $\mathrm{p}=0.05$. 
Tab. 6. Effect of season and water supply on concentration of tocopherol in tomato fruits $\left(\mu \mathrm{g} \mathrm{g}^{-1} \mathrm{FW}\right)(\mathrm{n}=4)( \pm \mathrm{SD})$

\begin{tabular}{|c|c|c|c|c|c|}
\hline Harvesting date & $\begin{array}{c}\text { Cultivars and } \\
\text { treatments }\end{array}$ & $\alpha$-tocopherol & $\beta$-tocopherol & $\gamma$-tocopherol & $\gamma$-tocotrienol \\
\hline \multirow[t]{4}{*}{06.8 .2010} & $\mathrm{BI}$ & $7.07 \pm 0.24^{d}$ & $0.71 \pm 0.01^{c}$ & $2.04 \pm 0.05^{b}$ & $0.19 \pm 0.01^{a}$ \\
\hline & $\mathrm{BC}$ & $4.85 \pm 0.30^{b}$ & $0.53 \pm 0.07^{\mathrm{ab}}$ & $2.02 \pm 0.03^{b}$ & $0.20 \pm 0.01^{a}$ \\
\hline & StI & $6.19 \pm 0.49^{c}$ & $0.65 \pm 0.05^{\mathrm{bc}}$ & $2.25 \pm 0.09^{c}$ & $0.26 \pm 0.01^{b}$ \\
\hline & $\mathrm{StC}$ & $7.14 \pm 0.22^{d}$ & $0.57 \pm 0.04^{\mathrm{b}}$ & $2.26 \pm 0.01^{c}$ & $0.24 \pm 0.01^{b}$ \\
\hline \multirow[t]{2}{*}{26.7 .2011} & StI & $6.85 \pm 0.68^{\mathrm{cd}}$ & $0.41 \pm 0.11^{\mathrm{a}}$ & $2.87 \pm 0.59^{c}$ & $0.63 \pm 0.07^{\mathrm{d}}$ \\
\hline & $\mathrm{StC}$ & $7.69 \pm 0.72^{d}$ & $0.36 \pm 0.12^{\mathrm{a}}$ & $3.43 \pm 0.66^{\mathrm{cd}}$ & $0.45 \pm 0.11^{\mathrm{c}}$ \\
\hline \multirow[t]{4}{*}{ 26.8.2011 } & BI & $3.93 \pm 0.65^{a}$ & $0.88 \pm 0.10^{d}$ & $1.21 \pm 0.28^{\mathrm{a}}$ & $0.33 \pm 0.07^{b c}$ \\
\hline & $\mathrm{BC}$ & $6.78 \pm 1.37^{\mathrm{cd}}$ & $0.91 \pm 0.04^{\mathrm{e}}$ & $1.55 \pm 0.24 \mathrm{a}$ & $0.26 \pm 0.04^{b}$ \\
\hline & StI & $4.29 \pm 0.60^{\mathrm{a}}$ & $0.86 \pm 0.15^{\text {de }}$ & $3.35 \pm 0.31^{\mathrm{d}}$ & $0.39 \pm 0.07^{c}$ \\
\hline & $\mathrm{StC}$ & $9.49 \pm 1.67^{\mathrm{e}}$ & $0.83 \pm 0.14^{\text {cde }}$ & $3.77 \pm 1.05^{\mathrm{cd}}$ & $0.56 \pm 0.04^{\mathrm{cd}}$ \\
\hline
\end{tabular}

BI: 'Brixsol' irrigated,BC: 'Brixsol' control, StI: 'Strombolino' irrigated, StC: 'Strombolino' control.

Values are reported as the mean \pm standard deviation. Data in the same column bearing the same superscript letter are not significant at $\mathrm{p}=0.05$.

variation of phenolic compounds is also closely correlated with the temperature regime during the fruit development period of tomato.

We have also measured tocopherol content and composition. Four components of tocopherols were identified in the examined tomato samples. There were determined $\alpha$-tocopherol, $\gamma$-tocopherol, $\beta$-tocopherol and $\gamma$ tocotrienol were determined in decreasing percentage respectively $\alpha$-tocopherol represented $48-70 \%$ of total tocopherols and $\gamma$-tocopherol had the second largest concentration (between 22-38\%) depending on treatment, while the remaining two were lower than $10 \%$ (Tab. 6). Control plants gave higher average $\alpha$-tocopherol concentration (except BI sample, in the first harvest in 2010), which is in agreement with Hwang et al. (2012).

\section{Conclusions}

The climatic conditions, particularly the precipitation was significantly different in the two investigated seasons, because 2010 was the rainiest year, but during 2011 there was drought. Increasing the water supply increased fruit yield but reduced ${ }^{\circ} \mathrm{Brix}$ significantly. On the other hand it is very important to mention that Brix yield increased significantly. Many studies have demonstrated that the ingredient content is fundamentally determined by the genetic nature of varieties, but it does not exclude the fact that environmental factors also strongly affect it. Irrigation decreased ingredients contents of individual fruits, by inducing more and larger fruits, and by its dilution effects, but the higher yield could compensate for the concentration loss of individual fruits by higher ingredients production per unit area. We have measured significantly higher carotenoids and polyphenols content in processing cherry type hybrid 'Strombolino' $F_{1}$. Cherry type shows significantly higher carotenoid contents, mainly lycopene, than large fruited cultivars. $\alpha$-tocopherol is the most abundant tocopherol in tomato fruits. In general, we can state that irrigation decreased (in most cases significantly) carotenoids, polyphenol and tocopherol concentration in tomato fruits.

\section{Acknowledgements}

This study was funded in part by Research Centre of Excellence (17586-4/2013/TUDPOL) Szent István University and KTIA_AIK_12-1-2012-0012 project.

\section{References}

Abushita AA, Daood HG, Biacs PA (2000). Change in carotenoids and antioxidant vitamins in tomato as a function of varietal and technological factors. J Agric Food Chem 48:2075-2081.

Abushita AA, Hebshi EA, Daood HG, Biacs PA (1997). Determination of antioxidant vitamins in tomatoes. Food Chem 60:207-212.

Barbagallo RN, Silvestro ID, Patanè C (2013). Yield, physicochemical traits, antioxidant pattern, polyphenol oxidase activity and total visual quality of field-grown processing tomato cv. Brigade as affected by water stress in Mediterranean climate. J Sci Food Agr 93:1449-1457.

Biacs PA, Daood HG (2000). Lipoxygenase-catalysed degradation of carotenoids from tomato in the presence of antioxidant vitamins. Biochem Soc Trans 28:839-845.

Clinton SK, Emenhiser C, Schwartz SJ (1996). Cis-trans lycopene isomers, carotenoids, and retinol in the human prostate. Cancer Epidemiol Biomark Prev 5:35-51.

Daood HG, Bencze G, Palotás G, Pék Z, Helyes L (2013). HPLC analysis of carotenoids from tomato using cross-linked C-18 column and MS detection. J Chromatogr Sci doi:10.1093/chromsci/bmt139.

Dumas Y, Dadomo M, Di Lucca G, Grolier P (2003). Effects of environmental factors and agricultural techniques on antioxidantcontent of tomatoes. J Sci Food Agric 83:369-382.

Favati F, Lovelli S, Galgano F, Miccolis V, Di Tommaso T, Candido V (2009). Processing tomato quality as affected by irrigation scheduling. Sci Hort 122:562-571. 
149

García-Valverde V, Navarro-González I, García-Alonso J, Periago MJ (2013). Antioxidant Bioactive Compounds in Selected Industrial Processing and Fresh Consumption Tomato Cultivars. Food Bioprocess Tech 6: 391-402.

Hanson PM, Yang RY, Wu J, Chen JT, Ledesma D, Tsou SCS, Lee TC (2004). Variation for antioxidant activity and antioxidants in tomato. J Amer Soc Hort Sci 129:704-711.

Helyes L, Lugasi A (2006): Formation of certain compounds having technological and nutritional importance in tomato fruits during maturation. Acta Alim 35:183-193.

Helyes L, Lugasi A, Pék Z (2006). Tomato fruit quality and content depend on stage of maturity. Hort Sci 41:1400-1401.

Helyes L, Lugasi A, Pék Z (2012). Effect of irrigation on processing tomato yield and antioxidant components. Turk J Agr For 36:702-709.

Helyes L, Pék Z, Lugasi A (2008). Function of the variety technological traits and growing conditions on fruit components of tomato (Lycopersicon lycopersicum L Karsten), Acta Alim 37:427-436.

Helyes L, Varga G (1994). Irrigation demand of tomato according to the results of three decades. Acta Hort 376:323-328.

Hungarian Meteorological Service (2011). Temperature forecast of Gödöllö, 15 Aug. 2011.

Hwang ES, Stacewicz-Sapuntzakis M, Bowen PE (2012). Effects of Heat Treatment on the Carotenoid and Tocopherol Composition of Tomato. J Food Sci 77:C1109-C1114.

Incerti A, Navari-Izzo F, Pardossi A, Izzoa R (2009). Seasonal variations in polyphenols and lipoic acid in fruits of tomato irrigated with sea water. J Sci Food Agr 89:1326-1331.

Kuti JO, Konuru HB (2005). Effects of genotype and cultivation environment on lycopene content in red-ripe tomatoes. J Sci Food Agr 85:2021-2026.

Liu K, Zhang TQ, Tan CS, Astatkie T (2011). Responses of fruit yield and quality of processing tomato to drip-irrigation and fertilizers phosphorus and potassium. Agronomy J 103:13391345.

Orcutt DM, Nilsen ET (2000). The physiology of plants under stress soil and biotic factors. New York, JohnWiley and Sons
Inc $696 \mathrm{p}$.

Patanè C, Cosentino SL (2010). Effects of soil water deficit on yield and quality of processing tomato under a Mediterranean climate. Agr Water Management 97:131-138.

Pék Z, Daood H, Nagyné MG, Neményi A, Helyes L, (2013). Effect of environmental conditions and water status on the bioactive compounds of broccoli, Cent Eur J Biol 8:777-787.

Pék Z, Helyes L, Lugasi A (2010). Color changes and antioxidant content of vine and post-harvest ripened tomato fruits. HortScience 45:466-468.

Pernice R, Parisi M, Giordano I, Pentangelo A, Graziani G, Gallo M, Fogliano V, Ritieni A (2010). Antioxidants profile of small tomato fruits: Effect of irrigation and industrial process. Sci Hort 126:156-163.

Rao VA (2006). Tomatoes, Lycopene and Human Health: Preventing Chronic Diseases. Caledonian Science Press, Inverness $238 \mathrm{p}$.

Riga P, Anza M, Garbisu C (2008). Tomato quality is more dependent on temperature than on photosynthetically active radiation. J Sci Food Agr 88:158-166.

Riggi E, Patanè C, Ruberto G (2008). Content of carotenoids at different ripening stages in processing tomato in relation to soil water availability. Australian J Agric Res 59:348-353.

Sánchez-Rodríguez E, Ruiz JM, Ferreres F, Moreno DA (2012). Phenolic profiles of cherry tomatoes as influenced by hydric stress and rootstock technique. Food Chem 134:775-782.

Seybold C, Frohlich K, Bitsch R, Otto K, Böhm V (2004). Changes in contents of carotenoids and vitamin $\mathrm{E}$ during tomato processing. J Agric Food Chem 52:7005-7010.

World Health Organization (1990). Diet, nutrition, and the prevention of chronic diseases. Report of a WHO Study Group. WHO Technical Report Series. No. 916. p 148.

Wudiri BB, Henderson DW (1985). Effects of water stress on flowering and fruit set in processing-tomatoes. Sci Hort 27:189-198. 